\title{
Tampilan Sapi Bali yang Diberi Hijauan dan Penambahan Suplemen (Silase dan Mineral) di Pulau Malan, Katingan
}

\author{
Harmini $^{1}$ dan M.A. Firmansyah ${ }^{2}$ \\ ${ }^{1)}$ Balai Penelitian Ternak. Jln Veteran III Ciawi Bogor \\ Email:harmini_miatun@yahoo.co.id \\ ${ }^{2)}$ BPTP Kalimantan Tengah. Jln. G. Obos Km 5 Palangka Raya
}

\begin{abstract}
ABSTRAK
Limbah pertanian jerami padi yang berlimpah belum banyak dimanfaatkan sebagai sumber pakan ternak. Penelitian ini dimaksudkan tampilan sapi Bali yang hanya diberi hijauan dan dengan penambahan suplemen silase jerami padi dan mineral. Silase jerami padi diberikan sebanyak $30 \%$ dan mineral diberikan sebanyak $4 \%$ dari total pakan, sementara hijauan diberikan $100 \%$. Sapi yang digunakan sebanyak 12 ekor dimana 7 ekor untuk perlakuan hijauan dengan ditambah suplemen dan 5 ekor untuk yang diberi $100 \%$ hijauan. Tampilan yang diukur yaitu panjang badan, lingkar dada, tinggi badan dan pertambahan berat badan harian (PBBH). Hasil penelitian menunjukkan bahwa panjang badan dan tinggi badan pada kelompok yang diberi suplemen lebih tinggi $(\mathrm{P}<0,05)$ dibandingkan pemberian hijauan $100 \%$. Sedangkan lingkar dada dan $\mathrm{PBBH}$ nyata lebih tinggi $(\mathrm{P}<0,05)$ pada penambahan silase jerami padi sebanyak $30 \%$ dan mineral 4\%. Penelitian ini menyimpulkan bahwa pemberian pakan hijauan ditambahkan 30\% silase dan 4\% mineral dapat meningkatkan lingkar dada dan PBBH pada sapi Bali.
\end{abstract}

Kata kunci: jerami padi, silase, mineral, sapi Bali

\section{The Performance of Bali Cattle Fed by Forage and Supplemented by Silage and Mineral in Malan Island of Katingan}

\begin{abstract}
Waste of rice straw is abundance available and not used as animal feed source. This study was aimed to compare the performance of Bali cattle fed by forage only and supplemented by straw silage and mineral. Total of 12 bali cattle was used. Given $30 \%$ straw silage and $4 \%$ mineral of total feed was represented by 7 Bali cattled. Amount of 5 Bali cattle was given 100\% forage. Measurement of body length, chest circumference, height and daily weight gain were measured. The results showed that the length and height in the group given supplements were higher $(P<0,05)$ compared to forage only. While the bust and $P B B H$ were higher and significantly different $(P<0,05)$. It was concludes that feeding forage and supplemented with silage and minerals can increase the chest circumference and PBBH in Bali cattle.
\end{abstract}

Keywords: rice straw, silage, minerals, Bali cattle.

\section{PENDAHULUAN}

Tantangan dalam meningkatkan produktivitas ternak ruminansia selalu terkait dengan penyediaan pakan berkualitas dengan harga kompetitif dan tersedia sepanjang waktu. Salah satu kelebihan dari ternak ruminansia adalah kemampuannya untuk memanfaatkan pakan berserat tinggi, seperti produk sisa pertanian yang tidak bersaing dengan kebutuhan manusia dan diubah menjadi daging. Sisa tanaman padi berupa jerami dapat digunakan sebagai salah satu sumber pakan ternak. Ketersediaan jerami padi sangat berlimpah, sering tidak digunakan sebagai pakan ternak. Nilai nutrisi jerami padi rendah. 
Menurut Takakashi et al. (2005) melaporkan sisa tanaman padi yang baru dipanen berpotensi untuk dibuat sebagai bahan silase (ensilase) dan dapat digunakan sebagai pakan ruminansia. Perlakuan ensilase sebagai upaya preservasi berbagai limbah basah (wet-by products) ataupun fermentasi dapat meningkatkan kualitas nutrisi bahan dan berfungsi sebagai serat kasar sebagai pengganti hijauan rumput. Sumber limbah jerami padi dapat diperoleh dari wilayah kering dengan kemarau yang panjang (Ginting, 2009).

Silase merupakan pakan ternak hasil fermentasi yang telah diawetkan dari tanaman, pakan hijauan, limbah dari produksi pertanian dan lain-lain yang dicacah, kandungan air pada tingkat tertentu yang disimpan dalam suatu tempat yang kedap udara (Salim, 2002). Tujuan pembuatan silase yaitu sebagai upaya pengawetan hijauan segar yang berlimpah dan diharapkan dapat menjadi solusi untuk mengatasi permasalahan kekurangan hijauan segar pada musim kesulitan pakan. Selain itu pembuatan silase dimaksudkan untuk mempertahankan atau meningkatkan kualitas hijauan makanan ternak.

Mineral sangat diperlukan oleh tubuh ternak dalam proses kehidupannya. Hal ini dikarenakan mineral berfungsi sebagai katalisator untuk mengaktifkan kerja enzim, menjaga keseimbangan asam basa, menjaga keseimbangan membran sel dan ikut berperan dalam aktifitas mikroba rumen selama fermentasi di dalam rumen. Georgievskill et al. (1982) melaporkan bahwa fungsi utama mineral pada ruminansia yaitu mempengaruhi simbiotik mikroflora di saluran pencernaan. Utomo (2011) memformulasikan bahwa hasil pemeriksaan contoh serum sapi Katingan menunjukkan sebagian besar di bawah standar kecukupan mineral $\mathrm{Cu}$.

Pertumbuhan merupakan tolok ukur yang paling mudah untuk mengukur produktivitas ternak, yang dilihat dari pertambahan bobot badan dan ukuranukuran tubuhnya (tinggi pundak, panjang badan dan lingkar dada). Herman et al.
(1985) melaporkan pertumbuhan ukuran dimulai dari tinggi pundak, panjang badan, lebar dada, dalam dada dan lingkar dada. Tujuan dari penelitian ini adalah untuk mengetahui tampilan sapi Bali yang diberi hijauan (100\%) dengan yang diberi tambahan silase dan mineral tampilan tersebut yaitu pertambahan berat badan harian $(\mathrm{PBBH})$, tinggi badan, panjang badan serta lingkar dada pada sapi Bali.

\section{MATERI DAN METODE}

\section{Waktu dan Tempat}

Penelitian ini dilakukan selama 5 bulan dari bulan Maret-Juli 2012, di Desa Buntut Bali, Kecamatan Pulau Malan, Kabupaten Katingan, Provinsi Kalimantan Tengah.

\section{Pembuatan Silase}

Jerami padi yang digunakan merupakan jerami padi segar. Jerami padi dipotong-potong dengan ukuran $3-5 \mathrm{~cm}$ menggunakan mesin pencacah (chopper). Jerami potongan dilayukan selama 48 jam untuk meningkatkan kandungan bahan kering dengan cara dihamparkan pada terpal. Perbanyakan bakteri asam laktat (BAL) dilakukan dengan cara mengencerkan 1/4 botol (250 ml EM4) dilarutkan kedalam air bersih 5 liter ditambahkan $1 \mathrm{~kg}$ gula merah diaduk secara merata. Dalam $100 \mathrm{~kg}$ jerami ditaburkan $4 \mathrm{~kg}$ dedak padi yang berfungsi sebagai aditif dan 5 liter air perbanyakan BAL tersebut dicampur secara manual. Campuran bahan dimasukkan sedikit demi sedikit kedalam plastik (polythylene) ukuran 100 liter dan dipadatkan dengan cara diinjak hingga cukup padat, ditutup rapat dan diikat erat ujungnya. Guna mencegah masuknya udara dari luar maka karung plastik yang telah terisi cacahan jerami tersebut dimasukkan dalam kantong plastik kedua (polythylene) dan disimpan selama 21 hari pada suhu kamar dalam kondisi anaerob.

\section{Mineral}

Mineral yang digunakan adalah mineral feed supplement, diberikan 
sebanyak $4 \%$ dari total pakan dengan cara mencampurkan kedalam pakan atau air minum.

\section{Perlakuan Pakan dan Ternak}

Sebelum diberikan kepada sapi, silase terlebih dahulu diangin-anginkan. Jika silase dibuka sore maka diberikan pada ternak esok paginya begitu pula sebaliknya. Membiasakan ternak mengkonsumsi silase dilakukan dengan cara pemberian silase secara bertahap. Minggu pertama silase diberikan sebanyak 5\%, minggu kedua $10 \%$, minggu ketiga $20 \%$, sampai sapi dapat mengkonsumsi silase sebanyak $30 \%$ pada minggu keempat.

Digunakan 12 ekor sapi betina muda yang dibagi menjadi 2 kelompok. Kelompok pertama terdiri dari 7 ekor sapi yang diberi pakan silase sebanyak $30 \%$ dari total pakan ditambahkan $4 \%$ mineral feed dan 5 ekor sapi lainnya diberikan pakan $100 \%$ hijauan.

\section{Pengukuran Tampilan Ternak}

Pengukuran tampilan ternak meliputi panjang badan, lingkar dada dan tinggi badan dilakukan $1 \mathrm{x}$ per bulan. Panjang badan (PB) diukur dari bahu ke tulang duduk (pin bone), menggunakan meteran dalam satuan $\mathrm{cm}$. Lingkar dada (LD) diukur dari titik dibelakang tulang belikat, kebawah melingkari bawah perut, dibelakang siku, menggunakan meteran dalam satuan $\mathrm{cm}$. Tinggi badan (TB) diukur dari jarak tegak lurus dari jarak tertinggi pundak sampai ke lantai/tanah, menggunakan tongkat dalam satuan $\mathrm{cm}$. Cara pengukuran tampilan ternak, lihat Gambar 1.

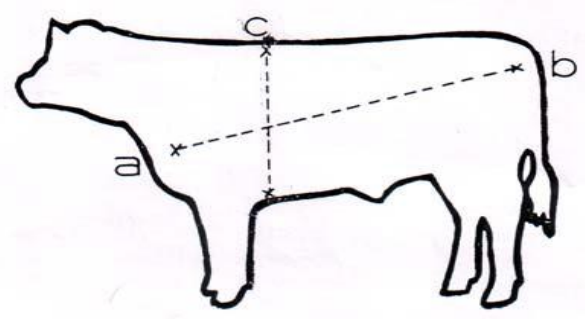

Gambar 1. Pengukuran panjang badan (a-b) dan lebar dada pada sapi (c-d)
Rumus untuk mengkonversikan panjang badan dan lebar dada ke dalam bobot badan ternak merujuk pada rumus Winter yang sudah dimodifikasi oleh Arjodarmono, sebagai berikut:

$$
\mathrm{BB}=\mathrm{PB} \times \mathrm{LD}^{2} / 10^{4}
$$

Keterangan:

$\mathrm{BB}=$ Bobot Badan $(\mathrm{kg})$

$\mathrm{PB}=$ Panjang Badan $(\mathrm{cm})$

$\mathrm{LD}=$ Lingkar Dada $(\mathrm{cm})$

\section{Pengukuran Pertambahan Berat Badan Harian (PBBH)}

Pengukuran Pertambahan Berat Badan Harian (PBBH) dilakukan dengan cara mengukur berat badan akhir-berat badan awal dibagi jumlah hari pemeliharaan, seperti rumus berikut ini:

$$
\mathrm{PBBH}=\mathrm{W}_{2}-\mathrm{W}_{1} / \mathrm{T}_{2}-\mathrm{T}_{1}
$$

Keternagan:

$\mathrm{PBBH}=$ Pertambahan Bobot Badan Harian $(\mathrm{kg})$

$\mathrm{W} 2=$ Berat badan akhir $(\mathrm{kg})$

$\mathrm{W} 1=$ Berat badan awal $(\mathrm{kg})$

$\mathrm{T} 2=$ Waktu akhir

$\mathrm{T} 1=$ Waktu awal

\section{Parameter dan Analisa Statistik}

Parameter yang diamati adalah panjang badan, lingkar dada, tinggi badan dan pertambahan berat badan harian. Data tampilan sapi dibandingkan dan dianalisis dengan Uji T tidak berpasangan (Steel dan Torrie, 1993).

\section{HASIL DAN PEMBAHASAN}

Pemberian hijauan (100\%) dengan penambahan silase jerami padi $30 \%$ dan mineral feed supplement 4\%, pada pakan sapi Bali berpengaruh nyata $(\mathrm{P}<0,05)$ terhadap pertambahan lingkar dada dan pertambahan berat badan harian $(\mathrm{PBBH})$. Namun tidak berpengaruh nyata $(\mathrm{P}>0,05)$ terhadap pertambahan panjang badan dan tinggi badan. Rerata pertambahan ukuran tubuh pada perlakuan pemberian hijauan $(100 \%)$ dan hijauan yang ditambah silase 
jerami padi $30 \%$ dan mineral feed supplement $4 \%$ selama tiga bulan, menunjukkan lingkar dada $8,857 \mathrm{~cm}$ dan 3 $\mathrm{cm}$, bobot badan pada $31,715 \mathrm{~kg}$ dan $12 \mathrm{~kg}$, panjang badan $3,14 \mathrm{~cm}$ dan $2,2 \mathrm{~cm}$, serta tinggi badan $3,517 \mathrm{~cm}$ dan $2 \mathrm{~cm}$, masingmasing pada sapi yang diberikan hijauan ditambah pakan suplemen dan $100 \%$ hijauan (Gambar 2). Hasil perolehan ini mengindikasikan bahwa pemberian kualitas pakan yang berbeda akan berpengaruh nyata pada pertambahan lingkar dada dan PBBH ternak.

Lestari et al. (2010) melaporkan bahwa pertumbuhan sapi PO dan PL (Peranakan Limosin) yang diberi makan rumput gajah kering dan 50\% konsentrat (campuran konsentrat pabrik $75 \%$ dan ampas kecap 25\%), menunjukkan pertumbuhan sapi PL yang lebih tinggi $(\mathrm{P}<0,05)$ dibandingkan dengan Sapi PO. Hal ini dikarenakan konsumsi pakan Sapi PL lebih tinggi $(\mathrm{P}<0,05)$ (Lestari et al., 2010). Ditambahkan pemberian pakan dengan level protein $11,03 \%$ mempengaruhi pertambahan lingkar dada, namun pertambahan bobot badan, pertambahan panjang badan dan pertambahan tinggi pundak yang diperoleh relatif sama (Adiwinarti et al., 2011). Pembuatan silase jerami padi mampu meningkatkan kadar protein dari 4,55 menjadi 9,41\% (Tabel 1). Dilaporkan jerami padi hasil fermentasi dengan menggunakan probion berpeluang sebagai pengganti rumput dan mampu mempertahankan konsumsi, kecernaan, pertambahan bobot hidup harian dan efisiensi ransum Simmental (Antonius, 2009). Pertumbuhan dapat dinilai sebagai peningkatan tinggi, panjang, ukuran lingkar dan bobot ternak muda yang sehat serta diberi pakan, minum dan mendapat tempat berlindung yang layak (staff.unud.go.id)

Tabel 1. Komposisi Nutrien Jerami Tanpa Olahan dan Jerami Hasil Fermentasi

\begin{tabular}{|c|c|c|c|c|c|c|c|}
\hline Jenis Jerami & $\begin{array}{l}\text { NDF } \\
(\%)\end{array}$ & $\begin{array}{l}\mathrm{ADF} \\
(\%)\end{array}$ & $\begin{array}{l}\text { Selulosa } \\
(\%)\end{array}$ & $\begin{array}{l}\text { Hemiselulosa } \\
(\%)\end{array}$ & $\begin{array}{c}\text { Lignin } \\
(\%)\end{array}$ & $\begin{array}{l}\text { Silika } \\
(\%)\end{array}$ & $\begin{array}{l}\text { PK } \\
(\%)\end{array}$ \\
\hline Tanpa Olahan & 72,41 & 46,72 & 35,91 & 25,69 & 6,13 & 7,12 & 4,55 \\
\hline Hasil fermentasi & 58,83 & 37,35 & 26,88 & 21,48 & 3,96 & 5,13 & 9,41 \\
\hline
\end{tabular}

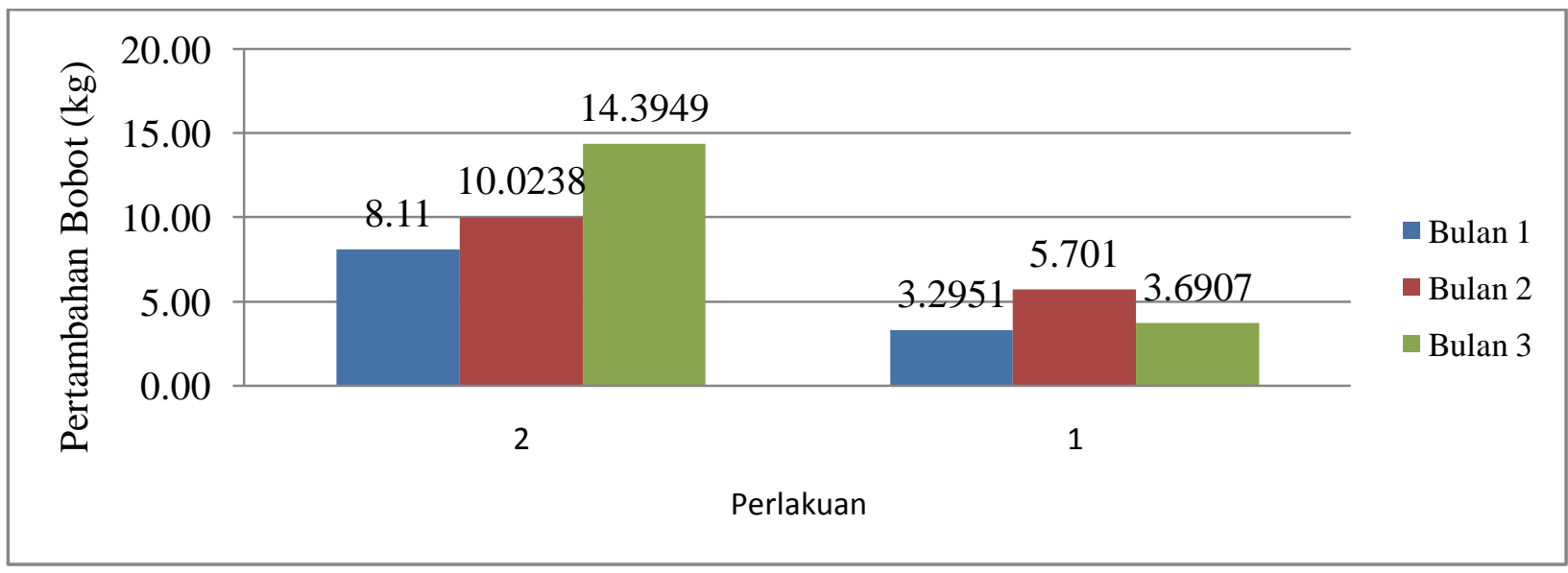

Gambar 2. Grafik pertambahan bobot badan sapi yang diberi 100\% hijauan (1) dan penambahan silase dan mineral (2) 
Pemberian pakan yang cukup dan memenuhi syarat dapat memunculkan sifat genetik yang baik, seperti pertumbuhan menjadi lebih sempurna dan cepat, persentase karkas menjadi lebih tinggi dan lebih tahan terhadap penyakit. Pemberian pakan pada ternak sapi, baik sapi potong maupun sapi perah harus diperhatikan kuatitas dan kualitas pakan sehingga pertumbuhannya tidak terganggu. Pemberian pakan yang tidak menjaga kuatitas dan kualitas pakan akan menimbulkan goncangan pertumbuhan pada sapi (Gambar 2). Pada 100\% hijauan terjadi peningkatan rerata panjang badan, lingkar dada dan tinggi badan dari bulan pertama dan bulan kedua, tetapi menurun pada bulan ketiga.

Fluktuasi pertumbuhan ini diduga karena penelitian dilakukan pada musim kemarau dan suhu tinggi sehingga pertumbuhan dapat menurun secara drastis. Hal ini juga disebabkan persediaan pakan dan daya cerna sapi hijauan berkurang. Kualitas pakan pada musim kemarau ditandai dengan hilangnya energi, mineral dan protein akibat kekurangan air. Hijauan pakan ternak berhenti tumbuh, kehilangan warna hijau, berserat dan berlignin tinggi, rendah ketersediaan mineral (staff.unud.go.id). Ditambahkan produksi dan kualitas nutrisinya berfluktuasi dan cenderung menurun tajam selama musim kemarau, terutama di daerah tropis (Salem et al., 2006). Hijauan yang diberikan pada ternak tidak lagi memenuhi syarat, bahkan jumlahnya tidak mencukupi kebutuhan ternak. Berbeda dengan pemberian silase jerami padi $30 \%$ dan mineral feed supplement $4 \%$, pertambahan panjang badan, lingkar dada dan tinggi badan relatif stabil. Pemberian pakan pada ternak ruminansia dalam bentuk silase memberikan keuntungan karena asam laktat dikonversi menjadi asam propionat yang merupakan prekursor glukosa (Lemosquet et al., 2004). Ditambahkan penambahan mineral mikro $\mathrm{Mn}, \mathrm{Cu}$ dan $\mathrm{M}+\mathrm{Cu}$ tidak mempengaruhi $\mathrm{pH}, \mathrm{NH}_{3}$ maupun VFA (Volatile fatty acid) secara in vitro.
Hanya pada penambahan mineral mikro Mn meningkatkan nilai KCBK (Koefisien Cerna Bahan Kering), sedangkan penambahan mikro mineral $\mathrm{Mn}+\mathrm{Cu}$ menurunkan nilai $\mathrm{KCBK}$ maupun KCBO (Koefisien Cerna Bahan Organik) (Fathul dan Waljizah, 2010).

\section{Panjang Badan}

Rata-rata pertambahan panjang badan harian $(\mathrm{PPBH})$ pada perlakuan hijauan dengan silase jerami padi $30 \%$ dan feed suplement mineral $4 \%$ dibanding $100 \%$ hijauan yaitu $0,035 \mathrm{~cm}$ dan $0,025 \mathrm{~cm}$. Pemberian pakan dengan penambahan silase $30 \%$ dan $4 \%$ mineral feed suplement tidak memberi pengaruh nyata $(\mathrm{P}>0,05)$. Pertambahan panjang badan tidak dipengaruhi oleh gemuk atau kurusnya ternak tetapi dipengaruhi oleh kerangka tubuh. Pertambahan panjang tulang pada ternak relatif menurun dengan semakin meningkatnya umur ternak. Rata-rata PPBH pada penelitian ini lebih rendah jika dibanding dengan hasil penelitian (Adiwinarti et al., 2011) yaitu pada sapi Jawa $0,09 \mathrm{~cm}$ dan pada sapi PO yaitu $0,054 \mathrm{~cm}$ yang diperlakukan dengan pemberian jerami padi dan konsentrat pada level protein yang berbeda (Lestari et al., 2010).

\section{Lingkar Dada}

Rata-rata pertambahan lingkar dada harian (PLDH) pada perlakuan hijauan dengan silase jerami padi $30 \%$ dan feed suplement mineral 4\% dibanding $100 \%$ hijauan yaitu masing-masing $0,98 \mathrm{~cm}$ dan $0,033 \mathrm{~cm}$. Pemberian penambahan pakan berupa silase $30 \%$ ditambah $4 \%$ mineral feed suplement berpengaruh nyata $(\mathrm{P}<0,05)$ terhadap pertambahan lingkar dada harian (PLDH) sapi Bali. Hal ini mengindikasikan bahwa kualitas pakan yang berbeda akan mempengaruhi pertambahan ukuran lingkar dada ternak. Rata-rata PLDH pada penelitian ini lebih tinggi jika dibanding dengan PLDH sapi Jawa 0,09 $\mathrm{cm} /$ hari (Adiwinarti et al., 2011) dan PO yaitu $0,075 \mathrm{~cm} /$ hari yang 
diperlakukan dengan pemberian jerami padi dan konsentrat pada level protein yang berbeda (Lestari et al., 2010).

\section{Tinggi Badan}

Rata-rata pertambahan tinggi badan harian (PTBH) pada perlakuan hijauan dengan silase jerami padi $30 \%$ dan feed suplement mineral 4\% dibanding $100 \%$ hijauan yaitu $0,039 \mathrm{~cm} /$ hari dan $0,022 \mathrm{~cm} /$ hari. Pemberian penambahan pakan berupa silase $30 \%$ ditambah $4 \%$ feed suplement mineral tidak berpengaruh nyata $(\mathrm{P}>0,05)$ terhadap pertambahan tinggi badan harian $(\mathrm{PTBH})$ sapi Bali. Hal ini dimungkinkan pertumbuhan tinggi pundak sudah mencapai maksimal.

Rata-rata pertambahan tinggi badan harian (PTBH) pada penelitian ini lebih rendah jika dibanding hasil penelitian (Adiwinarti et al., 2011) yaitu $0,08 \mathrm{~cm} /$ hari pada penelitian sapi Jawa dan sebesar 0,054 $\mathrm{cm} /$ hari pada penelitian. Sapi PO yang diperlakukan dengan pemberian jerami padi dan konsentrat pada level protein yang berbeda (Lestari et al., 2010).

\section{Pertambahan Berat Badan Harian (PBBH)}

Dari hasil analisa statistik diketahui bahwa pemberian silase jerami padi $30 \%$ dan feed supplement mineral $4 \%$ berpengaruh nyata $(\mathrm{P}<0,05)$ terhadap pertambahan berat badan harian $(\mathrm{PBBH})$ sapi Bali. Pemberian silase jerami padi $30 \%$ dan feed supplement mineral 4\% memberikan PBBH sebesar 0,35 $\mathrm{kg} /$ hari/ekor. Sedangkan pemberian pakan berupa $100 \%$ hijauan menghasilkan $\mathrm{PBBH}$ sebesar $0,14 \mathrm{~kg} / \mathrm{hari}$. PBBH dalam penelitian ini masih dalam kisaran hasil-hasil penelitian PBBH sapi Bali di beberapa tempat seperti di Bali, Sumatera Selatan dan Sulawesi Selatan (Muzani, 2010). Dengan pemberian ransum berupa rumput lapangan dalam bentuk segar, di Bali memberikan PBBH 0,1 kg/hari/ekor, (Nitis dan Lan; Muzani 2010) di Sumatera Selatan 0,21/kg/hari/ekor (Bakrie, 1990; Muzani, 2010) di Sulawesi Selatan memberikan $\mathrm{PBBH} 0,13 \mathrm{~kg} /$ hari/ekor 0,04 $\mathrm{kg} /$ hari/ekor $\quad 0,31 \quad \mathrm{~kg} / \mathrm{hari} / \mathrm{ekor} \quad 0,27$ $\mathrm{kg} /$ hari/ekor (Amril et al., 1990; Paat dan Winugroho, 1990; Paat et al., 1990; Pongsapan et al., 1991; Muzani, 2010). Sedangkan pemberian ransum rumput lapangan ditambahkan $30 \%$ konsentrat menghasilkan $\mathrm{PBBH} \quad 0,38$ kg/ekor/hari, rumput lapangan ditambahkan $30 \%$ dedak padi menghasilkan $\mathrm{PBBH} 0,29 \mathrm{~kg} / \mathrm{ekor} / \mathrm{hari}$ dan rumput lapangan ditambahkan $30 \%$ gaplek memberikan PBBH 0,17 kg/ekor/ hari (Nitis dan Lana, 1983; Muzani 2010). Sementara itu pemberian rumput lapangan ditambahkan 1,8\% BB konsentrat mempunyai PBBH 0,31 kg/ekor/hari (Amril et al., 1990; Muzani, 2010). Rumput lapangan ditambahkan $1 \mathrm{~kg}$ dedak padi menghasilkan PBBH 0,06 kg/hari/ekor rumput lapangan ditambahkan $2 \mathrm{~kg}$ dedak padi memberikan PBBH 0,12 kg/ekor/hari (Paat dan Winugroho, 1990; Muzani, 2010). Pemberian rumput lapangan ditambahkan $1 \mathrm{~kg}$ gamal memberikan PBBH 0,49 kg/ekor/hari (Paat et al., 1991; Muzani, 2010). Rumput lapangan ditambahkan 300 gr Urea Molasses Blok (UMB) menghasilkan $\mathrm{PBBH} \quad 0,46$ kg/ekor/hari (Sasangka et al., 1992; Muzani, 2010). PBBH lebih tinggi didapat dengan pemberian ransum berupa pucuk tebu ditambah 1\% BB Konsentrat dan tulang daun yang digiling memberikan $\mathrm{PBBH}$ mencapai 0,82/kg/ekor/hari (Wardani et al., 1982; Muzani, 2010). Namun PBBH hasil penelitian ini lebih rendah dari PBBH sapi Jawa yang diperoleh yaitu 0,63 kg/hari (Adiwinarti et al., 2011). Sementara itu pada penelitian sapi Ongole dan sapi Frisian Holstein (FH) yang diberi pakan $60 \%$ konsentrat dan jerami padi, menambahkan PBBH sapi PO sebesar 0,69 $\mathrm{kg}$ /hari (Kusuma et al., 2007).

Pakan berkualitas baik adalah pakan yang disukai ternak (palatabel), mudah dicerna serta tinggi kandungan proteinnya. Protein merupakan faktor yang esensial bagi perombakan pakan dalam rumen secara efisien. Bila kandungan protein pakan kurang 
dari 7\%, mikroba rumen tidak dapat mencerna pakan secara efisien, sehingga ternak akan mengalami penurunan bobot badan. Pertambahan bobot badan harian lebih dipengaruhi oleh konsumsi protein. Makin tinggi konsumsi protein, makin besar pula pertambahan bobot badan hariannya. Hal ini karena pertumbuhan ternak lebih membutuhkan protein dibanding energi. Dengan catatan kebutuhan energi ternak tercukupi (Bahar, 2012). Pemberian jerami padi akan mengakibatkan sapi kekurangan unsur-unsur protein/asam amino, lemak dan karbohidrat. Kadar serat kasar yang tinggi akan menyulitkan pencernaan sapi. Pembuatan silase mampu menurunkan Neutral Detergent Fiber (NDF), Acid Detergent Fiber (ADF), selulosa, hemiselulosa, lignin, silika serta mampu meningkatkan protein kasar (Tabel 1).

\section{KESIMPULAN}

Berdasarkan hasil penelitian ini dapat disimpulkan bahwa pemberian penambahan pakan 30\% silase jerami dan $4 \%$ mineral pada pakan ternak berpengaruh terhadap pertambahan lingkar dada dan bobot badan. Namun tidak berpengaruh terhadap pertambahan tinggi badan dan panjang badan. Pertambahan lingkar dada berkorelasi positif dengan pertambahan bobot badan ternak.

\section{DAFTAR PUSTAKA}

Adiwinarti, R., U.R. Fariha and C.M.S. Lestari. 2011. The growth of java bulls fed rice straw and concentrates containing different levels of protein. J. Ilmu Ternak Veteriner 16 (4): 260265.

Antonius, 2009. Potensi jerami padi hasil fermentasi probion sebagai bahan pakan dalam ransum sapi simmental. Buku I: 240-245. Bogor: Pusat Penelitian dan Pengembangan Ternak.
Fathul, F., dan S. Wajizah. 2010. Penambahan mikromineral $\mathrm{Mn}$ dan $\mathrm{Cu}$ dalam ransum terhadap biofermentasi rumen domba secara in vitro. J. Ilmu Ternak Veteriner 15 (1) : 9-15.

Georgievskii, B.N. Annenkov and V.T. Samokhin. 1982. Mineral nutrien of animals butterworths. London Boston Sydney Durban Wellington Toronto.

Ginting, S.P. 2009. Ulasan hasil-hasil penelitian di loka penelitian kambing potong. Bogor: Pusat Penelitian dan Pengembangan Ternak. Buku I: 43-51.

Herman, R., Suwartono dan Kadarman. 1985. Pendugaan bobot kambing peranakan etawah dari ukuran tubuh. Media Peternakan 10: 1-11.

Kusuma, I.M., R. Adiwinarti and A. Purnomoadi. 2007. VFA concentration in the rumen liquor of ongole crossbred and friesian holstein crossbred bulls fed $60 \%$ concentrate and rice straw as basal diet. Buku I: 77-80. Bogor: Pusat Penelitian dan Pengembangan Ternak

Lemosquet, S., S. Rigout, A. Bach, H. Rulquin and J.W. Blum, 2004. Glocosa metabolism in lactating cows in response to iso energetic infusion of propionic or duodenal glucosa. J. Dairy Science 87: 1767: 1777.

Lestari, C.M.R., R. Adiwinarti dan D. Perwitasari. 2010. Pertumbuhan sapi peranakan limosin dan peranakan ongole jantan yang dipelihara secara intensif. Buku I: 272-279. Purwokerto: Fakultas Peternakan, Universitas Jendral Soedirman.

Muzani, A. 2010. Petunjuk teknis memilih sapi bali. [cited 19 Agustus 2012]. Available from: $n$ tb. litbang.deptan.go.id/ind/pu/.../ Bakalan.p.

Salem, A.Z.M, Z.M. Salem, M.M. El-Adawy and P.H. Robinson. 2006. Nutritive evaluation of some browse tree foliages during the season: Secondary 
compounds, feed intake and invivo digestibility in sheep and goats. Animal Feed Science Technologi 127: 251-267.

Salim, R. dkk. 2002. Produksi dan pemanfaatan hijauan. Jakarta: Dairy Technology Improvement Project in Indonesia.

Steel R.G.D dan J.H. Torrie. 1993. Prinsip dan prosedur statistik suatu pendekatan biometrik. Jakarta: Gramedia Pustaka Utama.

Suarsana. 2010. Mengukur Produksi Ternak [Internet]. [cited 19 Agustus 2012]. Available from: Staff.unud.ac.id/.../wp/tumbuh.kemban g.ternak.pdf.
Takahashi, T., K. Horiguchi and M. Goto.2005. Effect of crushing rice and the addition of fermented juice of epiphytic lactic acid bacteria on the fermentation quality of whole crop rice silage and its digestibility and rumen fermentation status in sleep. Animal Science .J. 76: 353-358.

Utomo, B.N. 2011. Keragaman fenotipik dan genetik, profil reproduksi serta strategi Pelestarian dan Pengembangan Sapi Katingan di Kalimantan Tengah. Disertasi, Fakultas Peternakan. Bogor: Institut Pertanian Bogor. 